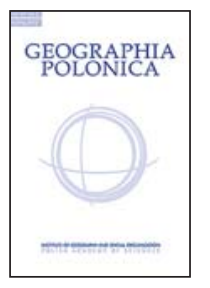

\title{
GENERATIONAL CYCLES AND CHANGES IN TIME AND SPACE
}

\author{
Mariusz Kowalski \\ Institute of Geography and Spatial Organization \\ Polish Academy of Sciences \\ Twarda 51/55, 00-818 Warsaw: Poland \\ e-mail: mar.kow@twarda.pan.pl
}

\begin{abstract}
The cyclical character of definite processes observed under both Polish and American conditions in fact emerges as of a universal nature, finding its analogies throughout the world, though first and foremost within the European cultural circle. It is also possible to speak of its far reaching synchronicity, encompassing change on both local and global scales. This is witnessed by successive culminations of cycles with the French Revolution and Napoleonic Wars, the revolutionary surges of the 1830s and 1840s, the events of the 1860s and 1870 s, the turbulences and wars of the early 20th century (notably World War I), then World War II, the great transformations of the 1980s, and the recently observed increase in political tension in various parts of the world (e.g. the Middle East, Ukraine, etc.). In the economic sphere the symptoms are shifts in the business climate, which can even be calculated by reference to quantitative indicators. Then, in the sphere of culture, it is possible to denote successive periods in literature and the arts. In the political sphere in turn, events that shape the state or territorial order are to be observed readily. The present article thus seeks to propose the existence of a universal and synchronous 30-40 years long generation cycle, which manifests itself in real symptoms in the world of politics, and for instance in the cyclicity seen to characterise intensity of change on the political map of Europe.
\end{abstract}

\section{Key words}

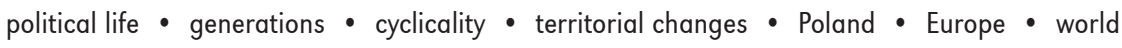

\section{Introduction}

It is on the basis of work in various different fields of research that theoretical concepts have been generated assuming that development (in the sense of a defined sequence of processes and transformation) is cyclical in character. In nature, cyclicity would seem to be something obvious and taken as read.
The earth spins on its axis and day follows night, while the Earth orbits the Sun elliptically, and the planet's tilt of axis away from the vertical ensure that there is a year broken down into seasons. And of course many biological rhythms have taken shape in the course of evolution, as organisms have adapted to the aforementioned cyclical events. Indeed, humankind's dependence on the 
natural environment made it necessary for the activity of our species also to be adjusted cyclically - in terms of both its life and work (Zawilska \& Nowak 2002).

All of this conditioning has its undoubted influence on the way we may come to regard the passage of time as somewhat cyclical in nature. And the earliest societies in prehistory indeed tended to see things as coming full circle, with some inevitability that a starting point would be returned to, not least because this was somehow being guided by the movements of the stars. More-developed outlooks worked to modify this view to a degree, with the Judaic and Christian traditions seeing time as entailing a definitive act of creation. Thus time came into existence as the world (read universe) came into existence, and from then on time's arrow was followed relentlessly in the direction of a future that at some point, however far away, would come to an end. This is then a linearity that only fully emerged in the Western world, and as a consequence of the modern science it has spawned in the last several centuries since the Enlightenment (Murziński 2008; Danielewicz 2015). Even then, the cyclical or wavelike nature of many phenomena and processes - not least in society - was not ignored by science, but was rather subject to efforts seeking its theoretical conceptualisation.

Where historiosophy and political geography are concerned, the concept of cylicity within polities gained considerably in popularity, having first been noted as some kind of regularity by the Arab-world academic Ibn Chaldun (1332-1406), who developed a theory on the political integration and disintegration of states that took the form of repeating cycles. In line with the concept, states arise as a result of subjugation from outside. As conquerors gradually integrate into the societies of the countries they have defeated, they lose the skill (or the determination or military strength) that allowed them to prevail politically at the outset. Empires fall in this way, while territory is then seized in the circumstances of a further wave of invaders from the exterior (Barnes \& Becker 1938).
In contrast, in the mid-19th century, Russian philosopher Nikolay Yakovlevich Danilevsky came out with a thesis involving a wavelike sequence of great civilisational and cultural formations (in the Near East, Greece, Rome and the West). Like organisms, these were seen to pass through some juvenile phase, before maturing, ageing and then dying, and in that way giving way to a next generation (Stefaniuk 2006).

Vilfredo Pareto (1912) explained cyclical political change by reference to the alternating occurrence of two categories of politicians, i.e. the lions and the foxes. While "lions" rule by dint of their strength, "foxes" did so by deploying their cunning. Rule by the "lions" is at first the obvious circumstance, but gradually "foxes" are able to penetrate the system, until more lions have enough of the situation and lead another revolution that allows them to take the full reins of power once again, providing for a cycle similar to the first one to begin all over again. Different researchers also claim to have noted the functioning of integrated revolutionary waves in different countries, given the influence of similar ideological inspirations emerging at more or less the same time (Katz 1997).

Economists and socioeconomic geographers very often resort to a concept of elongated waves as they seek to describe economic development after Kondratiev. This concept assumes that wavelike economic development has taken place since the onset of the Industrial Revolution, with a period of good economic conditions always giving way to slowdowns or economic crises (Kondratiev 1925).

One concept assuming cyclicity of socioeconomic processes is the world-systems theory put forward by Immanuel Wallerstein (2004) in line with the thinking of Fernand Braudel (1979). While applied to economic phenomena above all, this theory has also been used in the political sphere on many occasions. In contrast, a primacy of politics over economics is to be seen in the concept of hegemonic cycles after George Modelski (1987). Efforts to reconcile these two approaches were then 
made by Paul Kennedy (1987) and Andrzej Gałganek (1992), with the former linking political and military factors on the one hand with economic ones on the other, and with the latter perceiving a synchronisation of political and economic processes at global level (Moczulski 2010).

In most of the concepts referred to above, a single long wave lasts over a century, and often even for hundreds of years. Only the Kondratiev cycles are rather shorter. It would rather then be said that these are epochs in human history characterised by the domination of a given civilisation, empire or economic trend. There are in fact many reservations regarding cyclicity in this case. It is also hard to point precisely to a mechanism that would serve as the underpinning motor force. In the cases of investment (economic) cycles, the forces pushing them forward could tend to be revolutionary technological changes linking up with eras of new innovation. Under such circumstances the logic, but also the contradictions, characteristic for the capitalist economy would tend to ensure cyclicity of development. A phase of growth gives way to one characterised by stagnation, only for people's entrepreneurial skill to ensure a return to growth. Under this conceptualisation, cyclicity of economic development would then find reflection in political cycles via cyclicity of election campaigns, local politics and the tendency for hegemonic states to fall sooner or later (Taylor \& Flint 2000; Rykiel 2009).

However, as Victor Zarnovitz (1992) noted, not even proponents of the long-cycles concept have any steady view or agreed definition as to whether some of the waves exist at all. And agreement as to the calendar involved is even further away than that.

Against that background, cycles of generational length and frequency, in some way making reference to natural successions of generations and biological rhythms in general, would seem far more convincing as these seek to explain social change in the short or medium terms. So many researchers have naturally devoted decades of work to presenting the generational nature of certain phenomena at work in society. According to J. Garewicz whom a generation would be a group of people whose way of thinking has a decisive influence on the way they pass through the period of time that constitutes their generation. This whole-generation experience is nevertheless coped with in various different ways depending on the specific circumstances in which it comes into contact with certain events of a landmark or groundbreaking nature. Even then, the fact that this is a turning point in lives is clear, to the extent that the memory of it cannot be blurred, and later events are thus seen through the prism of it (Garewicz 1983; Adamczyk 2014).

There are many different concepts that regard age - or in fact membership of a defined generational group - as a key factor underpinning transformations in values. Generational change in connection with a change of social context gives rise to change as regards values. Ronald Inglehart's hypothesis revolving around shortage, the need for a feeling of security and socialisation holds that the socioeconomic situation was a dominant issue as the generation he referred to was growing up. The highest value is thus conferred upon this entity, to which access was limited in the growth period. It may thus be presumed that - in the case of social capital as linked strongly with the socio-cultural context - membership of a given generation is also a key fact differentiating between types of social capital generated (Inglehart 1977; Adamczyk 2014).

The distinct nature of attitudes in one generation that is upcoming as opposed to the other that is outgoing is in my view important for the understanding of the mechanism of generational change, and is perceived by Maria Ossowska. Her opinion was that the young have strong passions, all of which they would like to have satisfied. They are rather fickle as regards their needs, but these are strong for as long as they last, albeit inclined to fizzle out rather abruptly. They want superiority over others, and victory. They also want more than just money, having not yet suffered 
from a lack of the latter. They are also trusting, having never been cheated, and their lives are directed at the future, with that ability to trust also leaving them bolder than older people. The nature of old people is in turn viewed as rather the opposite. They are not sure of anything, and assign a value below the real one to everything. They are suspicious. Their needs are modest, but they are not generous because they now know how hard to it is to accumulate money, and how easy to lose what has been earned (Ossowska 1986; Adamczyk 2014).

Another matter is the mechanism underpinning generational conflict within a given family, wherein the old and young generations are separated by a distinct temporal divide and relationships of a particular nature. In society as a whole, things are different, since there is no clear boundary between older and younger generations given the lack of any periodicity to procreation on the scale of the group as a whole, with this meaning that age cohorts are giving way to others all the time.

For this reason, I would like to use this article to signal, not so much the existence of distinct generations and differences between them, as the separate nature of generational cycles 30-40 years long, which operate on the basis of a socio-demographic mechanism that entails the flow of age cohorts and the gradual replacement of those associated with the previous generational culmination, by those associated with the next one; the time separating these being 30-40 years, given the mean difference in age separating parents from their children (Kowalski 2016).

Despite similarly sounding notions (generation, generation cycle), the proposed concept does not apply to the generation in the understanding of Karl Manheimm. In the view of this researcher, collective and aware participation in shared fate and in ideas and concepts linked irrevocably with a generation's development, may lead to its potential being used, and to the emergence of a durable generational union characterised by a similar way of thinking or attitude to certain values that is at least widespread and at most almost universal within it (Mannheim 1936). This study deals with a more general and unconscious mechanism that drives social processes, in which Manheim's generations can be considered as a manifestation of significant social changes, but with its own autonomy and its own development mechanism.

\section{American generational cycles}

A concept involving much shorter cycles to account for changeability in American politics was advanced by Arthur Schlesinger. His idea was then developed further by his son, Arthur Schlesinger Junior. The cycles they proposed were supposed to last around 15-20 years and were characterised by the alternating occurrence of liberal and conservative periods. The tendency for change to take place was explained in terms of naturally-arising dissatisfaction with the activity of the political options in power, leading to a desire for its place to be taken by the option represented by the opposition. After a certain time, disillusionment would inevitably arise once again, with another switch being necessitated in that way (Schlesinger Sr. 1949; Schlesinger Jr. 1986, 1992). These processes were first and foremost linked with organisational dynamics and the evolution of public opinion (Goertzel 2001).

There are other researchers who advocate a change-of-the-generations aspect to the variability referred to above. One such is Michael Alexander (2005a), who views the ideas of the Schlesingers as similar to the popular concept advanced by William Strauss and Neil Howe (1991, 1997). In the view of the latter, social change was determined by generational reversals taking place every 15-25 years, but linking together into a ca. 80-year full cycle termed a saeculum. Each saeculum comprises four consecutive generation types repeating in each cycle, i.e. the idealistic (Prophet), the reactive (Nomad), the civic (Hero) and the adaptive (Artist). This concept was then related to the historical experience 
gained with American society. However, M. Alexander did not stop at linking together the two types of concept, seeking to add on to it a proposal by which Strauss-Howe generational cycles might be reconciled with the cycles after Kondratiev, to the extent that one Kondratiev cycle would correspond with a Strauss-Howe saeculum (Alexander 2002, 2005a).

In a further stage of his work, M. Alexander (2005b) arrived at the conclusion that a matter of key significance was 40-year cyclicity therefore encompassing two StraussHowe generational cycles. The periods distinguished in this way were termed paradigmatic cycles. These would be periods dominated by a certain model of social, political, economic and cultural tendencies that would then give way to an opposing model in the next paradigmatic cycle. In line with their dates of birth, groups of people would share the same model in the context of a paradigmatic generation. In Alexander's view, the creators of successive paradigms are the idealistic and civic generations conceived of under the Strauss-Howe concept, while the reactive and adaptive generations share a paradigm with their immediate predecessors. The paradigms concerned with idealistic and reactive generations are thus of themselves idealistic, while those based around civic and adaptive generations are inherently more pragmatic.

In the view of M. Alexander (2005a, 2005b), the paradigmatic cycle equates at the same time to the cycle to be noted on the US markets. The researcher refers to a phenomenon noted and remarked upon in American circumstances for a long time now, i.e. that consecutive cases of bear markets leading to crises or crashes in the 20th and 21 st centuries seemed to be spaced apart with remarkable evenness (separated by roughly 36 years). For his part, Polish market analyst Wojciech Białek notes that these successive fluctuations link up, not only with the financial markets, but also with the world of American politics. In analyses of market trends, the series of 20th-century crises kicks off with the bank panic of 1907 and ends with the rather similar fraught circumstances arising in 2008.

Unlike M. Alexander, as well as W. Strauss and N. Howe, Białek terms these very periods around 36 years long generational, given that this length coincides with the mean distance separating generations (father and child), as determined for the needs of genetic research by Trembaly and Vezina (2000) ${ }^{1}$. M. Alexander distinguishes a generation of similar length as paradigmatic, but this term would also seem to be attached to the psychological Strauss-Howe generations - only half as long, but difficult to see as generations in the light of demographic study (Kowalski 2016).

At the same time, Białek draws attention to the fact that each successive generational downturn is associated with a further geopolitical conflict normally culminating in war. This was the case for both World Wars, and then for the Cold War. The researcher also emphasises that the rhythm he calls "geopolitical" may be taken back in time before World War I in the context of the United States fighting the Spanish-American War at the end of the 19th century, with the Civil War a generation earlier apparently involving the grandchildren of those who fought in the British-American War, as well as the great grandchildren of participants in the American War of Independence (Białek 2009).

\section{Polish generational cycles}

When it comes to the experiences of Polish society, the existence of a 30- to 40-year generational cycle governing political and cultural life is not any new discovery, since this kind of issue has long been reflected in review studies from many different researchers and observers of the scene, albeit only making limited reference to phenomena of an economic nature.

\footnotetext{
1 In this context, it may be a little astounding to realise that Marcus Terentius Varro - a Roman scholar who died in 27 B.C. - accepted for the purposes of his own cogitations on the history of Rome that one generation equated to 35 years (Jaczynowska 1986).
} 
Norman Davies writes that: "the wheel of political fortune in nineteenth-century Poland revolved with a regularity beyond the bounds of mere coincidence". In his view, "the idea that the regular alternation of the two dominant ideologies was closely associated with the rise and fall of successive generations" has "strong credence". (...)"Neither Romantics nor Positivists could ever enjoy a run of more than three or four decades before disillusionment and failure destroyed their supremacy, and gave an opening for the revival of their opponents". According to Davies, in the whole 1795-1918 period there were "four complete revolutions of the generational cycle". $\mathrm{He}$ is convinced that what is important is not so much "identification of exact turning-points (although that is sometimes possible) but the identification of the alternating trends". Thus: "it is of little moment whether the close of the great Positivist era should be precisely dated to the revival of the patriotic demonstrations of 3 May 1891, to the formation of the PPS [Polish Socialist Party - editors' note] in 1892 or of the National Democrats in 1897, or the first outbreak of revolutionary violence on the Grzybowski Square in Warsaw on 13 November 1904". On the other hand, what is decisive is the fact that "the political situation in 1905 was fundamentally different from that of the Positivist supremacy ten or twenty years before" (Davies 1984: 184-185).

According to Davies, the regularities detailed above are not confined to the period of the Partitions, given that Poles fought with external powers both before and after that time. The historian feels that the political cycle in Poland might have taken in, not four or five generations coinciding with the times of partitioning, but 8 or even 10 . Where the number of generations is 9 , the first turning point in the list would be the Battle of Poltava (1709), as associated with the dethronement of King Stanisław Leszczyński; then leading all the way through (as the British historian had it) to the birth of "Solidarity" in 1980².

2 Looking at things from the perspective of 2018, one can doubtless refer to yet another generational turning (or
Davies identifies the cycle with modern political tradition, allowing him to advance a thesis to the effect that, in the case of Poland, this is much older than in the United States (with its 1787 Constitution), and in fact only slightly younger than in the parliamentary democracy that is the historian's native United Kingdom (Davies 1984).

As of the 1980s, Norman Davies was already noting that the regularities under discussion were not a new discovery, as a generational cycle in Polish political life had been discerned long before, and indeed in advance of the blessing given to the phenomenon by theoreticians (Davies 1984).

Generational theory is marked especially strongly in Polish research based around historical literature; and many workers have become convinced that consecutive eras in 19th- and 20th-century literature need to be associated with "breakthroughs" between one generation and the next. This is to say that there were Romantics, Positivists and Modernists, and so on. A precursor of this kind of thinking as regards ongoing change in the world of literature was Antoni Potocki (1912). His identification between successive literary generations and the passing of mere decades (with the "generations" of the "1960s, '1970s and so on) might suggest a thesis contrasting with the true generational concept, whereby a cycle lasts 30-40 years. However, Kazimierz Wyka (1946) notes that Potocki in his theory did not mention the move from Positivism through to Modernism, given that the significance of this was only thrown into

indeed tipping) point in Polish political life being reached with the 2015 elections. On the other hand, one may also seek to move further back into history. The author's knowledge in that domain allows him to point to a series of generational cycles marked by consecutive turning points beginning in the 15th century with the enactment of the Nihil Novi Constitution (1505), the so-called "Hen War" (1530), the Lublin Union (1569), the series of intrigues following the death of Tsarevich Dmitry, plus the efforts to install members of the Movilești family in Moldavia and the Zebrzydowski or Sandomierz Rebellion (all around 1600), the Polish-Muscovite War (1632), the Lubomirski Rebellion (1666), the Northern War (1700), the Dzików Confederation (1734), the Bar Confederation (1768), the Kościuszko Insurrection (1794), and so on. 
sharp relief by later researchers seeking to identify periods associated with different literary epochs (Nycz 2013).

A view of his own on generational cyclicity in politics was espoused by Wacław Balcerski, an outstanding Polish specialist in engineering and water management, the Rector of the then Gdańsk Polytechnic, and at the same time an MP in the 1957-61 Sejm that followed on from the famous political "thaw" induced by Stalin's death. In the course of a discussion among non-aligned members he expanded upon his view of Polish insurrections and risings, noting their cyclicity at this point. Successive generations seemed to have succumbed to some kind of myth regarding renewed struggle every $30-40$ years, as with 1794 , 1830, 1863, 1905 and 1944. The theory was therefore one by which disastrous failure gave voice to moderate common sense and realism in Polish society, with efforts then made to make good losses risings had generated. Balcerski saw Polish society as being symbolised by a climbing ant that falls back many times. In line with this cycle, Poles obviously showed restraint in 1956, because that date was far too close to the bold-but-catastrophic Warsaw Uprising of 1944. In the view of Balcerski, only around 1980 would the next "dangerous" period come along (Bierzanek 2006). With the benefit of hindsight, we might reasonably suggest that his presumptive vision was a correct one.

Also invoking the same cyclicity as Balcerski and Davies is Lech Mażewski, for whom Poland was moved to participate in dramatic freedom-seeking efforts every 30-40 years in the whole period from the time of the Bar Confederation of 1768-72 through to August 1980 (Mażewski 2004).

Observations of American society sustain a hypothesis that generational cycles are in operation, not only in regard to situations involving foreign enslavement (as Norman Davies supposed), but also as a kind of permanently-acting motor mechanism in public life that brings about political change. In the light of this, and drawing on the theses expounded by W. Balcerski, Davies and
L. Mażewski, it might have been anticipated that Poland would experience a next political culmination event around 2016 (given that this was 36 years after the push for freedom made in 1980). That hypothesis in fact gained presentation in an article from early 2014 (Kowalski 2014), as well as two further ones appearing in print in the first half of 2015 (Kowalski 2015a, 2015b). Indeed, if we accept that in Poland's case a non-violent political culmination came with the double election victory of the "Law and Justice" party in 2015 (with all its subsequent political consequenc$\left.\mathrm{es}^{3}\right)$, then it can perhaps be considered that the generational theory has gained yet further substantiation on Polish territory.

\section{The convergence of the Polish and American generational cycles}

Correlation or coincidence between phenomena to be observed in Poland on the one hand and the USA on the other, as well between the conclusions arrived separately on the basis thereof, allow it to be presumed that a quite universal phenomenon is at work. What is more, the generational changes to be noted in 19th- and 20th-century Poland and America do not merely occur with similar frequency, but can even be said to culminate at more or less the same time. The Bar Confederation of 1768-1772 only slightly precedes the American War of Independence (1775-1783), and even has a common hero in the person of Kazimierz Pułaski. In turn, Polish fighting with a view to achieving independence in the 1788-1815 period would seem to coincide with the British-American War of 1812, with links in both cases to Europe-wide events like the French Revolution and Napoleonic

\footnotetext{
3 As of 2018, stress is already being put on the significance of the political change that has followed on from the election victories achieved by PiS (Poland's "Law and Justice" party). The most extreme manifestation of the latter has been the dispute surrounding Poland's Constitutional Tribunal and then the wider reform of its judiciary - for many amounting to the most serious political crisis post-1989, and a shoe-in for inclusion in the history textbooks that future generations of Poles will learn from.
} 
Wars. The November Rising and Spring of the Nations in Poland coincided with the border dispute between the United States and Mexico of the 1830s and 1840s, while the November Rising of 1863-4 in some sense matches the American Civil War (1861-5). Both countries were then involved in both the First cycles. There is not only coincidence between dates here, but also some kind of qualitative resemblance between consecutive cycles, which are often of somehow alternating idealism or pragmatism. Also characteristic are linkups with the phenomenon of panic on Wall Street (Tab. 1) (Kowalski 2016).

Table 1. Key dates and trends for generation cycles in line with the concept addressed in the text

\begin{tabular}{|c|c|c|c|c|c|c|c|c|}
\hline Criterion & \multicolumn{8}{|c|}{ Cycles } \\
\hline Kondratiev Waves & \multicolumn{2}{|c|}{1} & \multicolumn{2}{|c|}{2} & \multicolumn{2}{|c|}{3} & \multicolumn{2}{|c|}{4} \\
\hline Ideological type & idealistic & pragmatic & idealistic & pragmatic & idealistic & pragmatic & idealistic & pragmatic \\
\hline Wall Street panic & - & - & 1828 & 1863 & 1907 & 1938 & 1974 & 2008 \\
\hline Schlesinger & 1776 & 1808 & 1834 & 1866 & 1909 & 1938 & 1971 & 2010 \\
\hline Strauss-Howe & 1781 & - & 1830 & 1861 & 1895 & 1938 & 1974 & 2015 \\
\hline $\begin{array}{l}\text { Culminating events } \\
\text { in Polish political history }\end{array}$ & 1768 & 1794 & 1830 & 1863 & 1905 & 1944 & 1980 & 2015 \\
\hline Polish literary periods & $\begin{array}{l}\text { sarma- } \\
\text { tism }\end{array}$ & $\begin{array}{c}\text { enlighten- } \\
\text { ment }\end{array}$ & $\begin{array}{l}\text { romanti- } \\
\text { cism }\end{array}$ & positivism & $\begin{array}{l}\text { modern- } \\
\text { ism }\end{array}$ & $\begin{array}{l}\text { authent- } \\
\text { ism }\end{array}$ & $\begin{array}{l}\text { postmod- } \\
\text { ernism }\end{array}$ & $\begin{array}{l}\text { present } \\
\text { day }\end{array}$ \\
\hline Proposed cycle name & american & $\begin{array}{l}\text { revolu- } \\
\text { tionary }\end{array}$ & romantic & positivist & modernist & $\begin{array}{l}\text { totalitar- } \\
\text { ian }\end{array}$ & $\begin{array}{l}\text { decom- } \\
\text { munising }\end{array}$ & $\begin{array}{l}\text { isolation- } \\
\text { istic }\end{array}$ \\
\hline
\end{tabular}

and Second World Wars (respectively 19141918 and 1939-1945), with there then being a sharpening of the East-West conflict in the late 1970s and early 1980s (i.a. as Ronald Reagan's Presidency began, Solidarity made its appearance and the Papacy of John Paul Il commenced). Today, we can also observe yet a further generational culmination (in the Middle East, Ukraine and the EU), in which both Poland and the USA proved to have various (sometimes joint) involvements ${ }^{4}$.

The similarity achieved by these two calendars may be noted as comparisons are made between the main dates of watershed moments in M. Alexander's paradigmatic cycle, as borrowed from Strauss-Howe' (as social moments) as well as Schlesinger (the beginnings of the liberal cycle) and dates of the culmination of Polish generational

4 Potentially attesting to coincidence in domestic policy are the election victories of PiS ("Law and Justice") in Poland in 2015, and of Donald Trump in the US in 2016.
Wojciech Białek was quite right in noting that each American generation has not only its financial crisis, but also its war. The same might in fact be said of Polish society (albeit with financial crises not being so well-marked here). After Norman Davies, we may further note that successive Polish insurgencies working towards national liberation are also associated with their cultural epochs. Likewise, following the proposal of $\mathrm{M}$. Alexander, it is possible to seek to reconcile the 30-40-year generational cycles of Poland and America with the concept after Strauss and Howe (their 'turning' being half of correct generational cycle, and their saeculum being two such cycles) and with the concept after Kondratiev (his wave being two generational cycles). It is particularly linked with the concept from M. Alexander himself, given that his paradigmatic cycle is a true generational cycle. And among all these it is the 30- to 40-year generational cycle that would seem to connect most closely with the natural (biological but 
also therefore social) cycle, in turn associated with the steady process by which a single generational cohort gives way to its successor.

It would furthermore seem that the phenomenon to be noted in Poland and America is yet more universal in nature, with analogous situations to be noted worldwide, if first and foremost in the European cultural sphere. Attesting to this are events of the 18th, 19th and 20th centuries, with the French Revolution and Napoleonic Wars, the various insurrections of the 1830s and 1840s, events of the 1860s and 70s, disquiet and war at the beginning of the 20th century (above all the First World War), the Second World War and then the great changes ushered in in the 1980s. This cycle provided a motor force for radical economic, cultural and political change. It also looks as if - in the Western world and societies influenced thereby - the process has been synchronised for some time now. In the economic sphere, the hallmarks are variations in business conditions based around measurable indicators. In culture, these would be successive eras in literature and art; in politics events that shape the systemic and territorial order. The latter prove especially interesting from the points of view of political and historical geography (Kowalski 2016).

This article thus hypothesises that there is such a thing as a universal, synchronised generational cycle, whose real hallmarks in the world of politics are - inter alia - intensified cyclical changes to be made out on the political map of Europe.

\section{The conditioning of a generational change}

The argumentation presented above does little to justify generational change every 15-20 years as Strauss and Howe would have it. However, there is no precluding what they would see as a generational turning point actually representing the first of the two phases making up each of the generational cycles, as M. Alexander (2005b) suggested in respect of the paradigmatic cycle. In this connection, several of the characteristics put forward by American researchers might really seem to make sense of the generational cycle lasting between 30 and 40 years.

A true generational cycle would last 30-40 years, and N. Davies and W. Białek (and indirectly also M. Alexander with his paradigmatic generation) would seem to take no issue with that. Equally, it would seem that, where social phenomena are concerned, this averaged value is of decisive importance, given that what counts vis-à-vis mass-scale phenomena is the resultant set of individual phenomena all combined together. It can also be presumed that the age difference between the generations referred to above has long assumed similar dimensions. It may well be that efforts at reproduction once began earlier, though they also ceased at a much greater age (while what is referred to all the time here is the average figure). In today's Western society, the process starts later, but also is brought to an end much sooner, with the effect that in most cases a person only has 1-2 offspring. Throughout, the mean difference in age between parents and their children has remained at a roughly similar level.

The sense of the generational change is conveyed very well by N. Davies's thinking, which was that: "the members of any new generation do not all come to maturity at exactly the same time, and any generational cycle must necessarily be driven by the combined effects both of the sudden and arbitrary impact of political events and of the more gradual, continual replacement of the ageing by the young. A decisive moment of change in public opinion can only occur when an absolute majority of adults is too young to remember the formative experiences of the preceding period". At some point, one generational cohort that has not consciously come through the culmination arrived at by the previous generation's turning point must gain a quantitative and qualitative advantage over the generational cohort that went before it.

Given the mean difference in age between generations of fathers and sons, the culmination of the process whereby the young begin 
to have the advantage over their predecessors arrives at the ages of 30-40 (see the dashed vertical line in Fig. 1). At this stage, in the circumstances of one kind or other of political enslavement, what ensues is social upheaval (uprising, revolution or act of protest). In turn, where the situation is a democratic one, it is then possible to experience the victory at elections of a grouping that speaks loudly and resolutely of the radical changes it is ready to usher in.

Generational change is a feature characteristic of all societies, hence the likely universal nature of the phenomenon being described here. An interesting case here would be that of the Kikuyu (Kenya's largest ethnic group). Tribal tradition in this case attaches considerable importance to the generational cycle, with a key event in the political system being an act by which a change of government in association with the ruling age class takes place (via the Ntuiko or Ituko ceremonies). One age class has a term in power lasting 30-40 years, with the reins then being taken by the next generation (age class) at around the time most of the firstborn grandchildren of the ruling generation reach adulthood (Chodak 1963).

This aspect of tradition of key significance in the life of the Kikuyu was thus the consequence of institutions in society being adjusted to the natural mechanism inherent in the generational cycle. Likewise it would seem that, informal as opposed to formal as the solutions may be, the generational cycle also operates in more-developed societies, including in Western civilisation. Equally, it is impossible not to notice that there are different institutional instruments (e.g. elections) in place here to guarantee the evolutionary transition from one generational cycle to the next. This sense of generational change was noted in their work by Strauss and Howe, albeit with the extra proviso that, where this path is blocked from the outside, it is revolutions or uprisings that take place, as was the case in the Partitioned Poland.

In his work, M. Alexander arrived at the conclusion that the generational cycle after
Strauss and Howe lasts just 18 years on average (Alexander 2005a, 2005b). It was then possible to proceed on the assumption that the true generational cycle (i.e. Alexander's paradigmatic one) lasts 36 years on average. This value can in turn be related to the mean difference in years separating generations, allowing this to be seen as the model value for the purposes of the present study (Fig. 1). A further assumption has been that the culmination points of a cycle (involving elections or revolutions) coincide with the middle of that period, as representatives of the upcoming generation start in some way to prevail over representatives of the generation that is outgoing. That moment is preceded by an 18-year period which sees a steady rise of new trends. In turn, there is a later further 18-year period during which a compromise is hammered out between the old and the new, with a temporary stabilisation being achieved in this way. A next cycle then begins (Kowalski 2016).

Selected as the reference point for the model demarcation of the cycles was the year 1980 (Fig. 1), in particular given the synchronised occurrence of catalysing breakthrough political events that year in many different countries.

\section{The universal nature of the generational cycle}

While assuming a possibility that the generational cycle is of a very widespread or even universal nature, it might reasonably be presumed that each national society will have its own separate calendar for the course such a cycle follows, and one that is unconnected with the calendar applying to other nations. However, it is impossible to ignore the fact that different societies do operate within larger communities dubbed civilisational circles (Koneczny 1962; Huntington 1996). Within these there are mutual interdependences, linkages and flows of ideas on culture, religion, language, the economy and politics. For a longer period now it has even been possible to speak of worldwide linkages that 


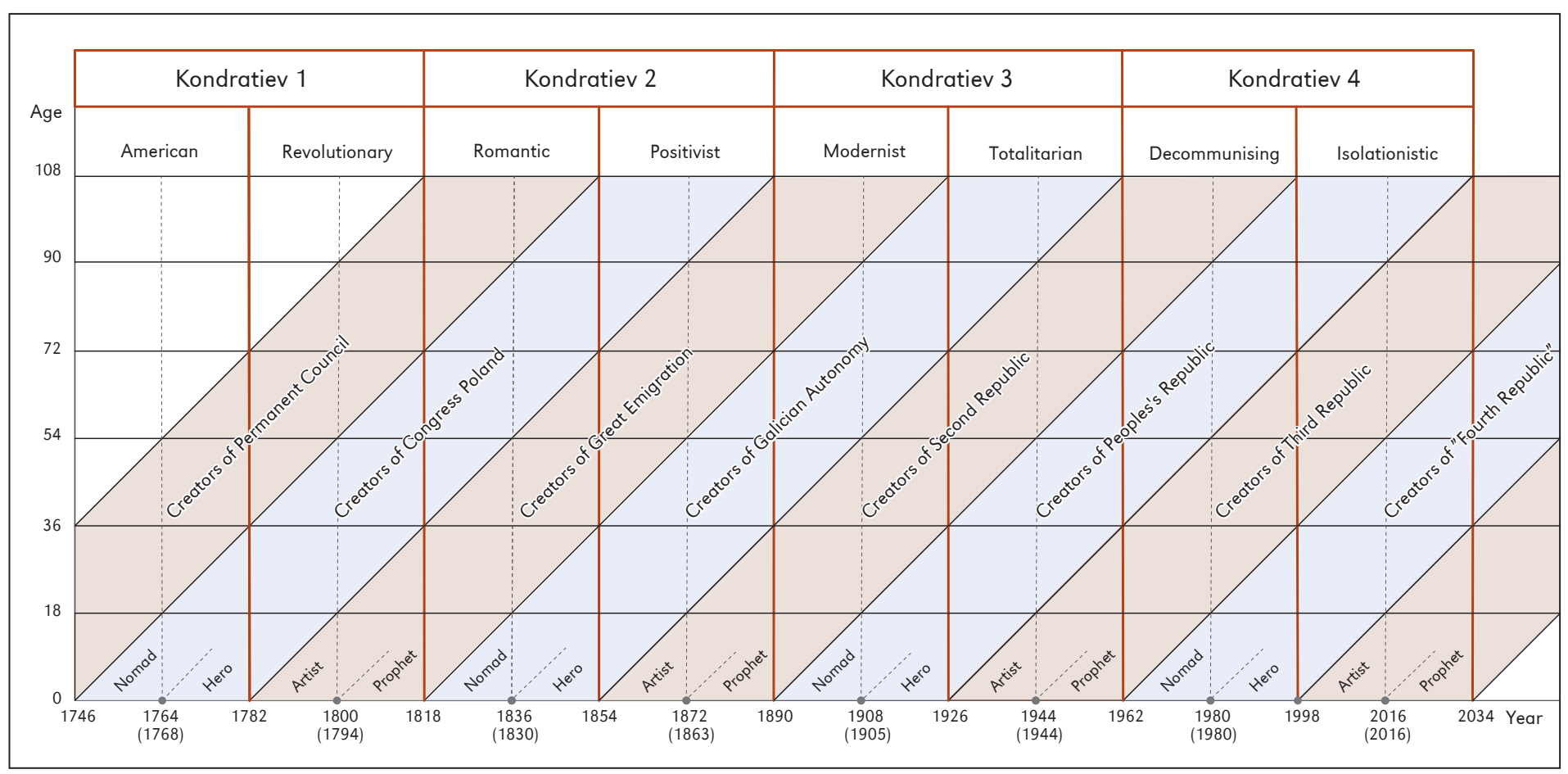

Figure 1. Model 36-year cohorts and generation cycles (and their names), with the dates of culminating events in Polish political history (in brackets) 
go beyond the separate civilisations and rather relate to the whole of humanity.

The European civilisational and cultural circle took shape in the rubble left behind from the Roman Empire. The societies belonging to that remained under the influence of the same centres and ideas. These first related to the Papacy and Empire, while later in the post-Westphalian (and post-Malthusian) worlds they related to the main superpowers (France, Germany, Britain and United States), as well as their centres of culture and business (Paris, Berlin, London and New York). Today, we also have large supranational players, notably the European Union. It is thus possible to speak of a far-reaching community of mutually interactive and diverse links between societies, as well as a harmonisation of fundamental phenomena and processes. While it is hard to say when this became a rule, it does seem certain that for a longer period now the societies of Europe (or broader European cultural circles) have been experiencing more or less simultaneously the culminations of a variety of similar trends, with the result that they are dragged into the same (kinds of) events of supranational significance that bring with them landmark changes in the nature of new breakthroughs of one kind or another (Kowalski 2016).

The first cycle to certainly encompass the whole of Europe was attendant upon the French Revolution and Napoleonic Wars. Moreover, this is a period regarded as giving a start to the Modern Era in general. Thereafter, intervals $30-40$ years long brought on successive waves ushering in new trends and changes. A fuller characterisation of these is to be found elsewhere (Kowalski 2014; 2015a, 2015b). However, from the political geography point of view what are interesting are the geographical and political outcomes (or even the fallout) arising from these successive waves. For whatever it is that the given generation strives for seems to culminate in a series of political, systemic and territorial changes finding their reflection on the political map of Europe (Fig. 2), as well as other parts of the world linked with our continent, or under its strong influence.

\section{The political map of Europe}

Especially major territorial change took place in the course of a cycle that may readily be termed Napoleonic, and lasted between 1782 and 1818. Its most spectacular events were naturally the French Revolution and Napoleonic Wars, but it brought a new political order (and cultural models) to one European country after another, evoking a lively response (be that positive or negative) among local communities. The period was responsible for an undermining of the significance of the gentry and aristocracy that left the position of the third estate strengthened. In addition, almost every military campaign prosecuted by the French Emperor resulted in further border shifts, as well as the establishment of new polities. While the Congress of Vienna strived to reverse these changes, that did not always prove possible. In this connection, many areas changed their political affiliation, as compared with the pre-1789 situation (Fig. 2). In Europe, those gaining most were Russia, Prussia and Austria. The (Polish-Lithuanian) Commonwealth of the Two Nations ceased to exist, with its lands being incorporated into those surrounding Empires. The Holy Roman Empire was transformed into several tens of German and Italian states, and the order established overall came to bear the name Vienna.

A next generational cycle suitable for being termed "Romantic" encompassed the years 1818-1854 and brought with it far more limited territorial change (Fig. 2). As a generation earlier, it was in France that the political ferment found its heartland. The first phase of the cycle nevertheless brought a failure for Russia's "Decemberists" (in 1825) and those participating in Poland's November Rising of 1830-1831. In contrast, Greece's insurrection ended in success, as did the revolution in Belgium. In turn, revolution in France in 1830 gave rise to the July Monarchy, which brought in bourgeois solutions, but was not able to avert the outbreak of the February 1848 revolution. This last event toppled the 


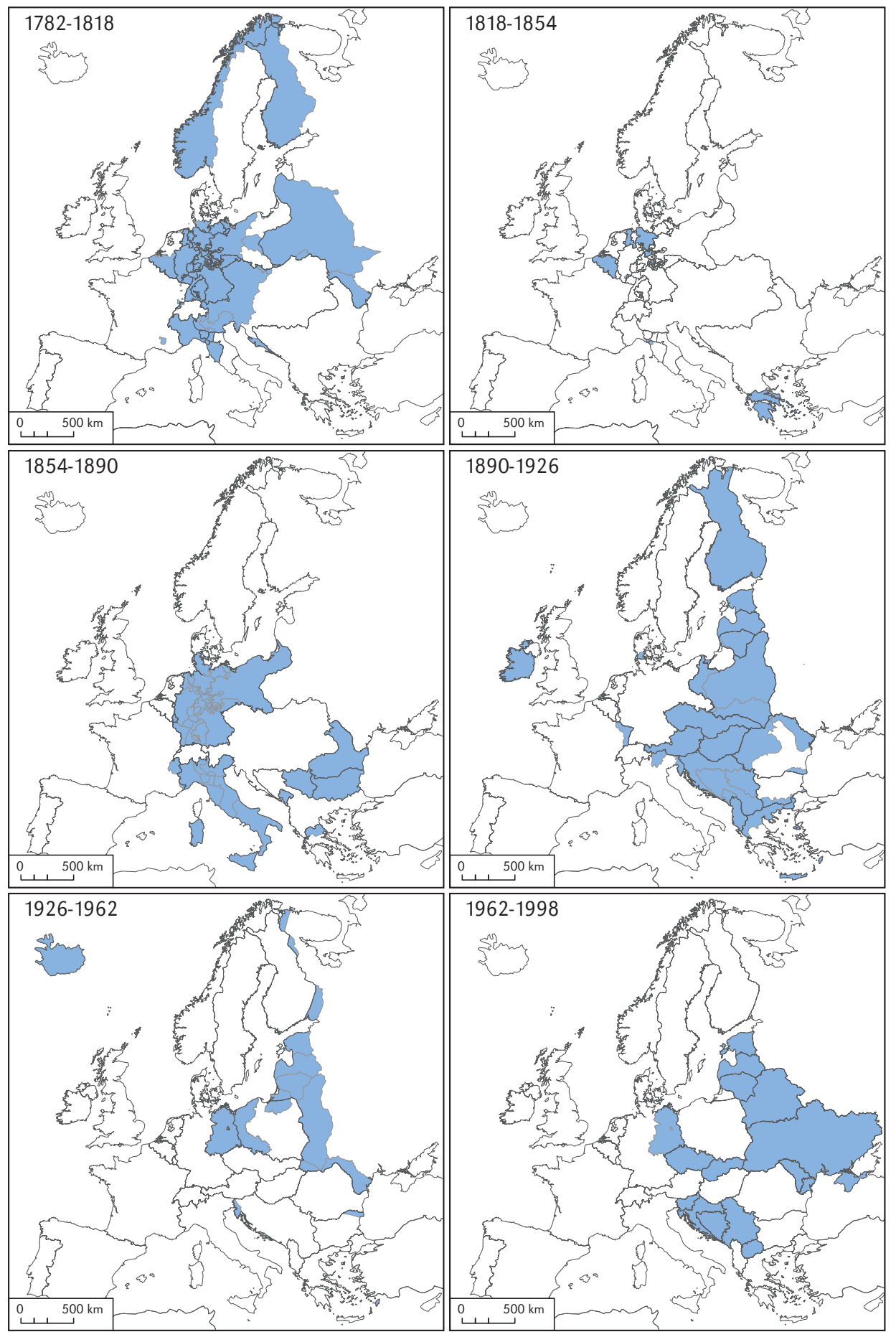

removed borders

continued or new borders

Figure 2. Persistent territorial changes in successive generation cycles 
Bourbons in France and set in train a series of events in other European countries that came to be termed the Spring of the Nations (1848-1849). On the Polish lands, this took in the parts partitioned by Prussia and Austria, while omitting the Russian-ruled sector that had experienced the November Rising, in this way serving as some kind of confirmation of the supplementing nature of these two further insurrections. Coming into existence at this point were an independent Greece and Belgium, while several small territories (including in Italy and Germany) lost their independence or experienced a change of allegiance. Far more major change involved political systems, with some states transformed into bourgeois constitutional monarchies (France, Sardinia and many German states). In others, the privileges of the gentry were curtailed, first and foremost to the benefit of the monarchy (as in Russia and the Habsburg Empire).

More major territorial change made itself felt in the next cycle, which covers the years 1854-1890 and may be termed Positivist (Fig. 2). In Poland, the January Uprising led to enfranchisement of the peasants, while in the USA the result was a bloody Civil War ending in victory for the Northern States and bringing an end to slavery. In Europe, the Battle of Königgrätz (otherwise Sadowa) took place in 1866 and put a stop to Austria's domination over Germany, with the way thus paved for a partial unification of the latter in the context of an arising Prussian Empire. The last solution become possible after Prussia defeated France in 1870, at the same time terminating the French Empire, putting in place the Third Republic and leading to the Paris Commune events of 1871 . The unification of polities to form Italy took place in the same period, while political change in the Habsburg Empire made possible the emergence of Austro-Hungary, as well as a measure of autonomy for the Austrianrun Polish province of Galicia. It was in these years that France and Denmark experienced losses of territory (to the benefit of Germany, while Austria and Italy ended up ceding land to Italy and France respectively. The last chord to this generational cycle in Europe came with the Russo-Turkish War and establishment of a new order in the Balkans. This setup gained its approval at the 1878 Berlin Congress. Achieving independence at Turkey's expense at that point were Romania, Serbia, Bulgaria and Montenegro. For its part, Greece was able to expand its territory.

The next generational cycle, which we have termed the Modernist (covering the period 1890-1926), also resulted in territorial changes (Fig. 2). One of the manifestations of the generational enlivenment this denoted was the appearance of modern national movements encompassing all parts of society. This period also brought an increased significance for the Marxist Left. Nationalist moods taking shape in such circumstances combined with social postulates to lead first to the Balkan Wars, and then to the outbreak of the First World War, and subsequently to the Bolshevik-inspired Russian Revolution. These events obviously culminated in a reshaping of the political map of Europe. At the expense of the hitherto highly-durable (Ottoman, Russian, Austro-Hungarian and Prussian) Empires that were to a great degree still relics of the feudal system, there appeared new nationstates that grew in size. Political change in many countries was associated with this, while the international order taking shape under these conditions was the one gaining ultimate acceptance at the 1919 Versailles Conference.

A great deal of territorial (Fig. 2) - and also systemic - change was associated with the next generational cycle, which occurred in the 1926-1962 period and may be dubbed Totalitarian. The ideological change associated with this made itself felt in the 1930s, with increase authoritarianism in both the Soviet Union and the Third Reich. In turn, making its way to power in Poland was the Sanacja camp, whose authoritarian manifestations were seen particularly clearly in the 1930s. The changes involved here also found their reflection in culture and art, with currents like Socialist Realism emerging in the USSR, as well as Intensivism and Authenticism in the Polish 
literature of the 1918-56 period, in line with the conceptualisation presented by Andrzej Chruszczyński (1998). With its huge dimensions and extreme brutality, the Second World War offered a kind of culmination of these tendencies. And thanks to the total defeat the Third Reich would ultimately suffer, the USSR grew in significance to become a world power able to impose territorial solutions of its own upon the whole of Eastern Europe. The main competitor for the USSR put up by the Western World was now the United States, and the international order worked out mainly by these two countries from 1945 came to be associated with the meeting venue of Yalta.

A further generational cycle to be dubbed decommunising and relating to the 1962-1998 period was associated with the serious crisis for left-wing ideologies faced, not only in the Eastern, but also in the Western, part of the divided world. A revival in neo-liberal thinking was ushered in by the coming to power of Margaret Thatcher's Conservatives in the UK, and the Republicans under Ronald Reagan in the USA. A first consequence was a sharpening of the confrontational stance pertaining between the two blocs, manifested not least in the 1979 Soviet invasion of Afghanistan, the respective 1980 and 1984 boycotts of the Moscow and Los Angeles Olympics (by the West and the Soviet Bloc respectively), and Reagan's announcement of his so-called "Star Wars" programme. It was also in this period that John Paul II became Pope (in 1978), the Solidarity Movement in Poland came into existence, and Mikhail Gorbachev came on the Russian political scene with his interest in reform, and the restructuring known as Perestroika (in 1985). The cycle also made itself very clearly felt in the countries of the Middle East, in the form of the Iranian Revolution, the Iran-Iraq War and civil war in Lebanon. While World War between the superpowers fortunately did not break out, there was an escalation of tensions in connection with economic and trade-related "warfare". The arms race was one manifestation of that. Furthermore, the two competing camps were behind many local or proxy conflicts that were pursued in many different parts of the world. These were conflicts having features of a rather specific kind of World War (i.e. amounting in some sense to a Third one). In turn, what we have been observing in recent years might be seen as some kind of counterpart of a Fourth World War. As a result of these events communism fell, and further changes of a territorial nature in East-Central Europe did ensue (Fig. 2).

The introduction of permanent territorial change in Europe is also possible in the current (1998-2034) cycle, which can be termed, for working purposes, as isolationistic. The strivings of a new generation have thus far been revealed in the course of events in Ukraine (the Orange Revolution, Revolution of Dignity, annexation of Crimea and war in Donbas), as well as Islamic countries (the Arab Spring and so-called Islamic State). During the same period, Europe experienced a severe economic and institutional crisis, felt with particular ferocity in the southern countries of Greece, Italy, Spain and Portugal. A discussion on the future shape of the European Union then ensued, as further influenced and magnified by a crisis surrounding the issue of migration. In this context, a decision of key significance was that taken by the people of the United Kingdom to leave the EU, with this also coinciding and in some way connecting with stronger separatist or independence movements in places like Catalonia and Scotland. The situation has its impact for a Russia keeping afloat on the basis of sales of raw materials to Europe, yet all the time looking for its new place on the world's political map following the collapse of the USSR and a still-tangible nostalgia for the loss of empire that seemed to denote.

It is hard to anticipate the direction in which cases are likely to develop. Much points to the fact that the order built by the previous generation (in Poland that of Solidarność, and in post-Soviet states of Perestroika) will be revised in the next few years, both globally and domestically. This must lead to the emergence of new territorial as well as political and systemic solutions, as well as new 
international configurations. The new order should finally crystallise around 2030, in order for it to survive through in general outline to the time of the next generational culmination around 2050 .

The intervals between the greatest periods of intensification of territorial change are not even, but in essence each cycle is characterised by such a process, which is then followed by a break that goes on until the next intensification occurring in the course of a new cycle (Fig. 3). In line with that kind of interpretation, territorial change would be a manifestation of the generational cycle, and one found to be least tangible in the course of the cycle linked with Romanticism. Equally, that period did witness particularly marked change in terms of the political and economic system (Fig. 4), this perhaps indicating that the energy of the new generation was in this case directed at the domestic problems different states were facing (Kowalski 2016).

Nevertheless, in the Romantic cycle it is also possible to see a limited intensification of territorial change processes, making themselves felt in both the first and second halves (around 1830 and around 1848 respectively) (Fig. 3).

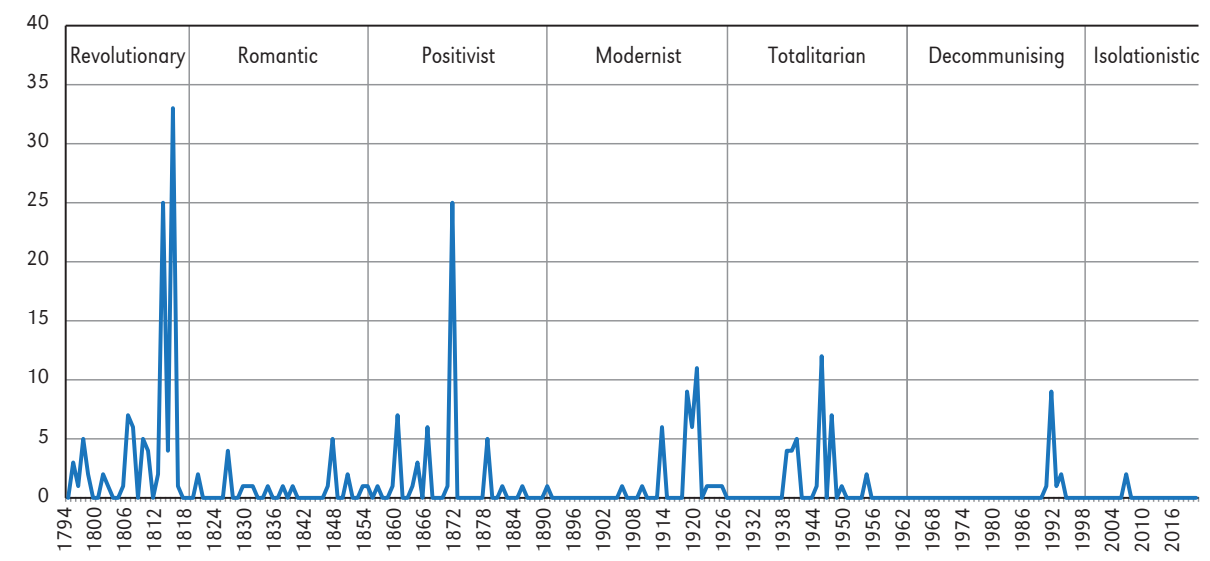

Figure 3. The rhythm to territorial change on the political map of Europe, as set against the periodical typology of generation cycles

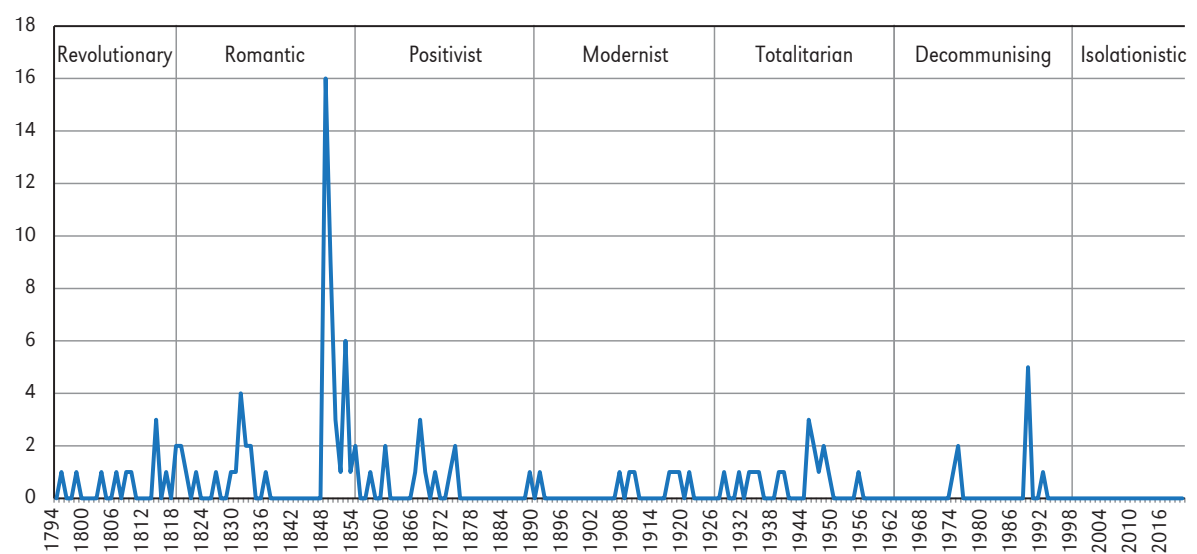

Figure 4. Systemic change in the countries of Europe (not accounting for appearance of new states), as set against the periodical typology of the generation cycles 
Unlike different states' moments of crisis on the financial markets or culminating political events, changes of territory (or in essence the conflicts giving rise to them) do not show distinct rules or tendencies, as we have seen already. There is nevertheless no denying that these are among the more important elements allowing the generational experiences to be distinguished from one another. The emergence of a conflict and establishment of a new territorial order on the basis thereof can be assumed to reflects a far greater number of factors than apply where the subject of consideration is either a given country's trends on the financial markets or its public mood. But sooner or later an "explosion" or outburst of some kind takes place, to allow the gathering tensions to be unloaded. And a decisive role in this is played by a combination of internal and international circumstances that are capable of shifting the conflict of paramount importance for the given cycle a couple of years forward or backwards in relation to the calendar derived theoretically.

\section{Summary}

The material analysed allows a thesis to be advanced to the effect that changes in society are in large measure the consequence of a biological rhythm operating widely but arising as the sum of many individual ones. A succession of breakthrough moments occur as a kind of critical mass is reached (a relevant number of people within an age-class), with this happening every $30-40$ years in connection with this being the mean age-gap separating parents and their children. In line with this difference, upcoming cohorts (generations) come to prevail over ones that are giving way some $30-40$ years after the previous cyclical culmination took place. And only then can there be radical change in the way society thinks or public opinion operates, with the ultimate result that a re-evaluation of convictions holding sway previously takes place, with postulates as regards change then being possible to act upon effectively.
The mechanism of the generational cycle thus needs to be understood by reference to demographic statistics, as a gradual arrival of an age cohort that had played no conscious part in a previous cyclical culmination, until such time as a quantitative advantage achieved allows for the coming into existence of a next such culmination and reported social change associated with it. However, at that moment there are present in society further age cohorts (of children and young people), who played no conscious part in the culmination of that cycle, but can be expected to give the power to the cycle that will be upcoming after a further $30-40$ years. This leaves developing culminations of successive year-classes as the motor force behind the series of generational cycles and their culminations, with the mean difference in age between parents and children ensuring that these culminations occur every $30-40$ years.

The proposed understanding of the nature of generational change need not imply a rejection of earlier proposals as to how the phenomenon may be understood. Involved in particular here is the Strauss-Howe generational theory, as the most commented upon and made use of in explaining social phenomena. M. Alexander considers that a Strauss-Howe generation of 18 years' duration on average comes within a single paradigmatic cycle, with the latter needing to be identified with the true generational cycle proposed here. In turn, according to M. Alexander, two paradigmatic cycles would make up one Strauss-Howe' saeculum.

In the first place, it is possible to recognise adjacent Strauss-Howe generations as forming two phases of a single generational cycle. However, there is a need for a certain shift in the Strauss-Howe configuration in order for it to match the cycle that is proposed here. Though adjacent to each other, the so-called Silent Generation and Baby Boom Generation have traditionally been considered assigned to two different periods of the saeculum type (and hence also two different paradigmatic cycles after M. Alexander). In fact, however, the configuration put forward here sees 
their activity making up a decommunising generational cycle. The activity of Generation $X$ and Generation $Y$ would then match with the isolationist generational cycle, while Generation $Z$ belonging to the same saeculum would need to be linked to the next generation belonging to the new saeculum (thus far assigned no name given its status as belonging to the future). The moment of culmination of the cycle would then coincide with the transition between each of the pairs of such generations. Differences would be accounted for in this way. The earlier generation (the older one of the cycle) - which can recall the earlier culmination taking place while its members were still young - would start its adult activity prior to the culmination of the cycle of its own activity, making contact first and foremost with people gaining their experience through the previous cycle (mainly its younger generation). The later generation (the younger one of the cycle), not having its own experience and recollections as regards the previous culmination, begins its adult activity in the vicinity of its cycle, first and foremost making contact with people belonging to the earlier (older) generation of that same cycle, or else with younger people who are to become the motor of the new cycle as the older generation.

Given the attempt at reconciliation with the saeculum after Strauss and Howe, the proposed interpretation (and chronology thereof) necessitates a shift of that saeculum by one Strauss and Howe generation. This would be two generational cycles following on from each other, i.e. four Strauss and Howe generations, but with the Prophet generation identified under their concept not being in a position to start off the saeculum. The same applies to the Hero generation. Rather the beginning would need to be provided by either the Nomad or the Artist generation. All in fact depends on which cycles to link up together into the saeculum. Regardless of that, one pair it would seem sensible to identify separately as such a unit of time would need to be formed by opposite tendencies (i.e. idealistic as set against pragmatic), with some whole being generated by mutual- ly augmentative parts. After Vilfredo Pareto, the saeculum would commence with an idealistic generational cycle (of "lions"), only to end up with a pragmatic generational cycle (of "foxes"). For this reason, the beginning of the newly configured saeculum would be the Artist generation, because in the system proposed here it starts the idealistic generation cycle (e.g. Silent Generation would begin the decommunization cycle).

A question also remains as to whether the saecula identified in this way can be somehow related to the cycles after Kondratiev (as M. Alexander suggests), or whether the phenomena being described and accounted for are in fact entirely unrelated. In the case of the last saeculum, it would seem that it ought to be started off by the Silent Generation (the older generation of the decommunising cycle), while ending with the Millennial Generation (i.e. the younger generation of the isolationist cycle). This is the saeculum of nuclear energy, television, space flight and universal motorisation (i.e. the $4^{\text {th }}$ wave in the meaning of Kondratiev). Prior to that, the saeculum was that of the two World Wars, as well as the development of electrical technologies and chemistry (in Kondratiev's third wave). Still earlier, the saeculum was that of steel and railways (Kondratiev's second wave of Romanticism and Positivism), while even before that it was the development of steam power and the textile industry that was involved (the first wave after Kondratiev, including the American and French Revolutions) (Tab. 1, Fig. 1).

Accepting the reality of existence of a true (30- to 40-year) generational cycle, and bearing in mind the cyclicity to change and the occurrence of events associated with it, it is hard to avoid concluding that this cycle was the main motor force behind life in society in the period under analysis (i.e. 1789-2015). Furthermore, this seems to be the case both within particular societies (states, countries, regions or local communities) and more widely on the international scene. Apparently, more far-reaching social change would not be possible without it. The generations after 
Strauss and Howe would be component parts, while saecula and the Kondratiev waves corresponding with them would arise from two mutually-augmentative generational cycles (i.e. the idealistic and the pragmatic).

Furthermore, a generational cycle can be presumed to have operated previously also (before 1789), albeit not so globally (or even continent-wide), but rather decided for each society separately. Somewhat tangentially to the main consideration here, possible culminations in Poland have been pointed to, beginning in the year 1505. For these too it would most likely be possible to find international points of reference. Irrespective of the ideological aspect to social, economic, political or cultural change, the basic catalyst thereof - and perhaps indeed the fundamental underlying mechanism - would seem to be the generational cycle recurring every 30-40 years (or in fact at the 36-year intervals arising as the average value determined in this work for the period of the last 250 years). It can thus be presumed

\section{References}

AdAmczyk M., 2014. Grupa pokoleniowa jako czynnik różnicujacy typ wytwarzanego kapitału społecznego w Polsce. Zeszyty Naukowe KUL, vol. 57, no. 1(225), pp. 55-80.

Alexander M.A., 2002. The Kondratiev cycle: A generational interpretation. San Jose-New York: Writers Club Press.

Alexander M.A., 2005a. Investing in a secular bear market. Lincoln, NE: iUniverse.

AleXander M.A., 2005b. The paradigm cycle model. http://www.safehaven.com/article/2975/ the-paradigm-cycle-model [30 June 2016].

Barnes H.E., BeCKer H.P., 1938. Social thought from Lore to Science. Boston, Mass.: D.C. Heath.

BIAŁEK W., 2009. Cykl pokoleniowy. Blog Wojciecha Białka - Komentarze finansowe analityka CDM PKO SA, http://wojciechbialek.blox.pl/2009/12/ Cykl-pokoleniowy.html [30 June 2016]. that an end will not be to history, political science and political geography until such time as the generational cycle in its demographic (and consequently also social) sense ceases to exist.

The acquaintanceship gained with the above regularities would also seem to bring us much closer to an understanding of the phenomenon of transience. Without it, and without a succession of generational cycles, development - or change of social significance - of any kind would become impossible. Equally, if people lived forever and there was no succession of generations, social change would have no chance to take place, or at least the consequence of it would not be so far-reaching. And there would be no dynamics (including development); merely a kind of hanging on.

\section{Editors' note:}

Unless otherwise stated, the sources of tables and figures are the authors', on the basis of their own research.

Bierzanek R., 2006. Przez wiek XX: wspomnienia i refleksje. Warszawa: Wyższa Szkoła Handlu i Prawa im. Ryszarda Łazarskiego w Warszawie.

Braudel F., 1979. Civilisation matérielle, économie et capitalisme, XVe-XVIIle siècle. Tome 3: le temps du monde. Paris: Armand Colin.

Chodak S., 1963. Systemy polityczne 'Czarnej' Afryki. Warszawa: Książka i Wiedza.

ChruszCZYŃSKI A., 1998. Intensywizm i autentyzm: (1918-1956). Cz. 1, Na fali przyboju. Bydgoszcz: Wydawnictwo Uczelniane Wyższej Szkoły Pedagogicznej.

Danielewicz Z., 2015. Nie taki prosty. Meandry linearnej koncepcji czasu w chrześcijaństwie. Studia Kołobrzesko-Koszalińskie, vol. 22, pp. 229-242.

Davies N., 1984. Heart of Europe: The Past in Poland's Present. Oxford: Oxford University Press. 
DomańSKI R., 2005. Geografia ekonomiczna. Ujęcie dynamiczne. Warszawa: Wydawnictwo Naukowe PWN.

GAtgAneK A., 1992. Zmiana w globalnym systemie międzynarodowym: Supercykle i wojna hegemoniczna. Poznań: Uniwersytet im. Adama Mickiewicza.

GareWiCz J., 1983. Pokolenie jako kategoria socjofilozoficzna. Studia Socjologiczne, no. 1, pp. 75-87.

Goertzel T., 2001. Generational Cycles in Mass Psychology: Implications for the George W. Bush Administration, International Psychohistorical Association's 24th Annual Convention, June 8, 2001, www.crab.rutgers.edu/ goertzel/ cycles.htm.

Huntington S.P., 1996. The clash of civilizations and the remaking of world order. New York: Simon \& Schuster.

INGLEHART R., 1977. The silent revolution: Changing values and political styles among western publics. Princeton: Princeton University Press.

JACZYNOWSKA M., 1986. Historia starożytnego Rzymu. Warszawa: Wydawnictwo Naukowe PWN.

Katz M.N., 1997. Revolutions and revolutionary waves. New York: St. Martin's Press.

KenneDY P., 1987. The rise and fall of the great powers: Economic change and military conflict from 1500 to 2000. New York: Vintage Books.

Kondratev N.D., 1925. Bolšije cikli koniunktury, Voprosy koniunktury, 1, 1, s. 28-79.

KONECZNY F., 1962. On the plurality of civilisations. London: Polonica Publications.

KowALSKI M., 2014. Cykle pokoleniowych buntów - od Konfederacji Barskiej do Majdanu. Najwyższy Czas!, 14 (5 April), pp. 38-40.

Kowalski M., 2015a. Czy Rosja upadnie jak Prusy? - ułomne podstawy wschodnioeuropejskich imperiów (Rosjanie szukaja Hitlera). Najwyższy Czas!, 12 (21 March), pp. 7-9.

Kowalski M., 2015b. Czy Kukiz podzieli los Tymińskiego. Najwyższy Czas!, 22-23 (30 May-6 June), pp. 18-20.

KowaLSKI M., 2016. Cykle pokoleniowe w czasie i przestrzeni. Przegląd Geograficzny, vol. 88, no. 4, pp. 489-510.
MannhelM K., 1936. Ideology and Utopia. London: Routledge.

MAŻEWSKI L., 2004. Powstańczy szantaż. Warszawa: Ksiq̨żka i Wiedza.

MoczUlSKa L., 2010. Geopolityka. Potęga w czasie i przestrzeni. Warszawa: Bellona.

ModelSKI G., 1987. Long cycles in world politics. London: Macmillan.

MurzIŃSKI P., 2008. Koncepcja czasu u Koheleta. Rocznik Teologii Katolickiej, vol. 7, pp. 135-143.

Nycz R., 2013. Język modernizmu: Prolegomena historyczno-literackie. Toruń: Wydawnictwo Naukowe Uniwersytetu Mikołaja Kopernika.

Ossowska M., 1986. Socjologia moralności. Zarys zagadnień. Warszawa: Wydawnictwo Naukowe PWN.

Pareto V., 1916. Trattato di sociologia generale. Firenze: G. Barbèra.

RykieL Z., 2009. Globalizacja a kodeks geopolityczny. Kultura - Historia - Globalizacja, no. 5, pp. 119-132.

SChlesinger A.M. (Jr.), 1986. The cycles of American history. Boston: Mifflin.

SCHLESINGER A.M. (Jr.), 1992. The turn of the cycle. The New Yorker, no. 68 (November 16), pp. 46-54.

SCHLESINGER A.M. (Sr.), 1949. Paths to the present. New York: MacMillan.

Stefaniuk T., 2006. Danilewski, panslawizm i wielość cywilizacji. Lublin: Wydawnictwo Uniwersytetu Marii Curie-Skłodowskiej.

Strauss W., Howe N., 1991. Generations: The History of America's Future, 1584 to 2069. New York: William Morrow and Company.

Strauss W., Howe N., 1997. The fourth turning: An American prophecy. New York: Broadway Books.

Taylor P., Flint C., 2000. Political Geography: World-economy, nation-state and locality. 4th edition, London-New York: Prentice Hall.

Tremblay M., Vézina H., 2000. New estimates of intergenerational time intervals for the calculation of age and origins of mutations. The American Journal of Human Genetics, vol. 66, no. 2, pp. 651-658. 
WALLERSTEIN I., 2004. World-systems analysis: An introduction. Durham: Duke University Press.

WYKA K., 1946. Antoni Potocki. Pamiętnik Literacki, 36, 3-4, pp. 345-357.

Zarnovitz V., 1992. Business cycles: Theory, history, indicators, and forecasting. Chicago: University of Chicago Press.
ZAWILSKA J.B., NoWAK J.Z., 2002. Rytmika okołodobowa i zegar biologiczny. Sen, vol. 2, no. 4, pp. 127-136.
(C) Mariusz Kowalski

(C) Geographia Polonica

(C) Institute of Geography and Spatial Organization

Polish Academy of Sciences - Warsaw • 2019
Article first received • December 2018

Article accepted • August 2019

Open acces article under the CC BY 4.0 license 